\title{
PENGARUH KOMPETENSI MANDOR TERHADAPKUALITAS PELAKSANAAN KONTRUKSI GEDUNG DI MALANG RAYA
}

\author{
Hariyono Seputro Youngky Pratama ${ }^{1}$, Sri Murni Dewi ${ }^{2}$ \& Ruslin Anwar ${ }^{3}$ \\ 1,2\&3Jurusan Teknik Sipil, Fakultas Teknik, Universitas Brawijaya Malang \\ Alamat Korspondensi: Jl.MT. Haryono 167, Malang 65145, Indonesia \\ E-mail: civil@brawijaya.ac.id
}

\begin{abstract}
The purpose of this study was: (1) to analyze the factors that affect the competence of foreman on the quality of construction of the building performance in Malang. (2) to know the relationship of variables that affect the competence of supervisors on the performance of the quality of building construction in Malang. The research was carried out on several samples of foreman in Malang. The sampling technique used is the judgmental technique (purposive). The statistical tool used in this study is Structural Equation Model (SEM) to determine the relationship of variables that affect the foreman's competence on the quality of construction of the building performance in Malang.

The analysis showed that foreman's competency factors affecting the performance of the quality of building construction in Malang are competency skills, personal and management. From the result of this research noted that there is a significant effect between skills variables, personal variables and management variable on the quality of buildings construction in Malang. Based on these result, it is advisable to conduct further research for other types of work that can be seen in more depth the competence of foreman.
\end{abstract}

Keywords: foreman competence, quality of building construction

\section{PENDAHULUAN}

Bertolak belakang dengan peranannya sebagai ujung tombak pada pelaksanaan konstruksi yang menggunakan sistem mandor, mandor tidak memperoleh cukup perhatian dalam berbagai pembahasan akademis tentang manajemen konstruksi. Mandor adalah partisipan aktifitas konstruksi yang khas di Indonesia. Padanan yang paling dekat dengan profesi ini diluar negeri dikenal dengan nama foremen. Manajemen seharusnya mempertimbangkan foremen sebagai seorang kunci di lapangan(Hinze, et al.1981).

Walau tidak ada jumlah yang pasti, jumlah mandor di Indonesia diperkirakan sudah mencapai ratusan ribu orang. Jumlah ini sangat signifikan untuk dibina dan dikelola untuk meningkatkan mutu dan proses jasa konstruksi di Indonesia.

Mandor mengkoordinasi banyak tenaga kerja kotruksi di Indonesia. Belum ada alternative pengganti yang dapat diterima oleh pelaku usaha jasa kontruksi untuk mengganti sistem mandor ini (Zen,1997). Sebagai gambaran Soendaroe (2000) mengemukakan mandor kontruksi di Jakarta mengkoordinir tenaga kerja antara 30 sampai 200 orang.

Meskipun peranannya sangat penting dalam pelaksanaan kontruksi, namun mandor belum dapat memberdayakan dirinya sendiri (Musyafa', 2003). Belum ada asosiasi profesi mandor yang dapat berperan aktif dalam meningkatkan keahlian. Tidak adanya jenjang karir terukur menyebabkan periode waktu kerja mandor bervariasi, yaitu empat sampai delapan tahun. Ini terlalu singkat jika dibandingkan dengan independent foremen di Filipina yang memakan waktu sepuluh sampai dua puluh tahun (Zen,1997).

Berangkat dari acuan yang minim, pada penelitian ini dicoba untuk mengidentifikasi kompetensi mandor dari berbagai aspek kecakapan terkait dengan lingkup pekerjaan mandor dalam pelaksanaan, yang diduga merupakan elemen pembentuk kompetensi mandor secara utuh.

Tujuan yang ingin didapat dari penelitian ini adalah: 
1. Untuk mengetahui faktor apa yang mempengaruhi kompetensi mandor terhadap kinerja kualitas pelaksanaan kontruksi gedung di Malang Raya.

2. Untuk mengetahui hubungan dari variablevariabel yang mempengaruhi kompetensi mandor terhadap kinerja kualitas pelaksanaan kontruksi gedung di Malang Raya.

\section{METODE PENELITIAN}

\section{Konsep Penelitian}

Metode penelitian yang digunakan adalah Structural Equation Model (SEM). Metode ini digunakan untuk mengetahui hubungan dari variabelvariabel yang mempengaruhi kompetensi mandor terhadap kinerja kualitas pelaksanaan kontruksi gedung di Malang Raya.

Pengumpulan data sampel dilakukan dengan menggunakan kuesioner. Populasi dalam penelitian ini adalah seluruh mandor di Malang Raya. Teknik pengambilan sampel yang digunakan adalah purposive sampling.

\section{Variabel Penelitian}

Variabel-variabel dalam penelitian ini dapat diklasifikasikan sebagai berikut:

Penelitian ini akan mengukur variabel-variabel sebagai berikut:

a. Ketrampilan (X1)

Sebagai variable ketrampilan, indikatornya dijelaskan oleh lima belas variabel sebagai berikut:

- X1a :Gambar kerja

- X1b : Pengawasan

- X1c :Estimasi

- X1d :Keselamatan kerja

- X1e : Jadwal kerja

- X1f : Kualitas bahan

b. Personal (X2)

Sebagai variable personal, indikatornya dijelaskan oleh sembilan variabel sebagai berikut:

- X2a : Pengalaman kerja

- X2b:Seleksi

- X2c: Komitmen membangun kepercayaan c. Manajemen(X3)

Sebagai variable sosial, indikatornya dijelaskan oleh tujuh variabel sebagai berikut:

- X3a : Pengarahan

- X3b :Pemahaman

- X3c : Financial dan likuiditas

- X3d : Insentive

- X3e :Penyelesaian konflik

d. Kualitas konstruksi gedung (Y1)

Sebagai variable kualitas konstruksi gedung, indikatornya dijelaskan oleh tiga belas variabel sebagai berikut:

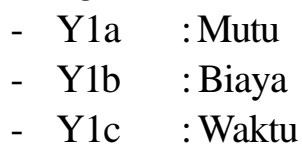

\section{Metode Analisis Data}

Analisis data menggunakan model persamaan struktur (Structural Equation Modeling/SEM) dari program Amos 18 dan SPSS versi 16. Langkah pengujian permodelan SEM adalah sebagai berikut :

1. Pengembangan model berbasis konsep dan teori prinsipnya menganalisis hubungan kausal antar variabel eksogen dan endogen, sekaligus memeriksa validitas dan reliabilitas instrumen penelitian.

2. Mengkonstruksi Diagram Jalur (Path Diagram).

3. Konversi diagram jalur ke dalam persamaan struktural dan model pengukuran persamaan didapat dari diagram jalur yang dikonversikan.

4. Memilih Matrik input dan Estimasi Model

5. Menilai Masalah identifikasi

6. Evaluasi Goodness of Fit

7. Interpretasi dan Modifikasi Model

\section{Hipotesis Penelitian}

Berdasarkan tujuan penelitian, tinjauan teoritis, dan kerangka konseptual serta penelitian terdahulu maka penelitian tersebut di atas maka dapat dikemukakan hipotesis sebagai berikut:

1. Variabel Ketrampilan yang terdiri dari gambar kerja, pengawasan, estimasi, keselamatan kerja, jadwal kerja dan kualitas bahan mempunyai pengaruh yang signifikan terhadap Kualitas Pelaksanaan. 
2. Variabel Personal yang terdiri dari pengalaman kerja, seleksi serta komitmen membangun kepercayaan dan komunikasi mempunyai pengaruh yang signifikan terhadap Kualitas Pelaksanaan.

3. Variabel Manajemen yang terdiri dari Pengarahan, Pemahaman, Financial dan Likuiditas, Insentive serta Penyelesaian konflik mempunyai pengaruh yang signifikan terhadap Kualitas Pelaksanaan

\section{HASIL DAN PEMBAHASAN}

\section{Deskriptif Variabel Penelitian}

\section{Deskriptif Variabel Ketrampilan (X1)}

Tabel 1. Persentase jawaban responden variabel ketrampilan

\begin{tabular}{ccccccc}
\hline \multirow{2}{*}{ Indikator } & \multicolumn{7}{c}{ Persentase Jawaban Reponden } & \multirow{2}{*}{ Rata-rata } \\
\cline { 2 - 6 } & $\mathbf{1}$ & $\mathbf{2}$ & $\mathbf{3}$ & $\mathbf{4}$ & $\mathbf{5}$ & \\
\hline Gambar Kerja (X1.1) & 0 & 2 & 28 & 60 & 10 & 3.78 \\
Pengawasan (X1.2) & 0 & 0 & 42 & 50 & 8 & 3.66 \\
Estimasi (X1.3) & 0 & 0 & 40 & 40 & 20 & 3.8 \\
Keselamatan Kerja (X1.4) & 0 & 0 & 44 & 42 & 14 & 3.7 \\
Jadwal Kerja (X1.5) & 0 & 0 & 34 & 52 & 14 & 3.8 \\
Kualitas Bahan (X1.6) & 0 & 8 & 40 & 42 & 10 & 3.54 \\
\hline \multicolumn{7}{c}{ Rata-rata keseluruhan } \\
\hline
\end{tabular}

\section{Deskriptif Variabel Personal (X2)}

Tabel 2. Persentase jawaban responden variabel personal

\begin{tabular}{cccccccc}
\hline \multirow{2}{*}{ Indikator } & \multicolumn{9}{c}{ Persentase Jawaban Reponden } & \multirow{2}{*}{ Rata-rata } \\
\cline { 2 - 6 } & $\mathbf{1}$ & $\mathbf{2}$ & $\mathbf{3}$ & $\mathbf{4}$ & $\mathbf{5}$ & \\
\hline Pengalaman Kerja (X2.1) & 0 & 4 & 38 & 36 & 22 & 3.76 \\
Seleksi (X2.2) & 0 & 4 & 30 & 52 & 14 & 3.76 \\
Komitmen membangun & 0 & 4 & 34 & 42 & 20 & 3.78 \\
\hline kepercayaan dan komunikasi (X2.3) & & & & & \\
\hline
\end{tabular}

Deskriptif Variabel Manajemen (X3)

Tabel 3. Persentase jawaban responden variabel manajemen

\begin{tabular}{ccccccc}
\hline \multirow{2}{*}{ Indikator } & \multicolumn{7}{c}{ Persentase Jawaban Reponden } & \multirow{2}{*}{ Rata-rata } \\
\cline { 2 - 7 } & $\mathbf{1}$ & $\mathbf{2}$ & $\mathbf{3}$ & $\mathbf{4}$ & $\mathbf{5}$ & \\
Pengarahan (X3.1) & 0 & 6 & 28 & 46 & 20 & 3.8 \\
Pemahaman (X3.2) & 0 & 0 & 14 & 58 & 28 & 4.14 \\
Financial dan Likuiditas (X3.3) & 0 & 6 & 36 & 40 & 18 & 3.7 \\
Insentive (X3.4) & 0 & 4 & 24 & 58 & 14 & 3.82 \\
Penyelesaian Konflik (X3.5) & 0 & 6 & 32 & 42 & 20 & 3.76 \\
\hline & Rata-rata keseluruhan & & & 3.84 \\
\hline
\end{tabular}


Deskriptif Variabel Kualitas Pelaksanaan (Y)

Tabel 4. Persentase jawaban responden variabel kualitas pelaksanaan

\begin{tabular}{ccccccc}
\hline \multirow{2}{*}{ Indikator } & $\mathbf{9}$ & $\mathbf{2}$ & $\mathbf{3}$ & $\mathbf{4}$ & $\mathbf{5}$ & \multirow{2}{*}{ Rata-rata } \\
\cline { 2 - 6 } & $\mathbf{1}$ & 6 & 30 & 50 & 14 & 3.72 \\
\hline Waktu (Y.1) & 0 & 6 & 38 & 36 & 20 & 3.7 \\
Biaya (Y.2) & 0 & 6 & 26 & 50 & 18 & 3.8 \\
Mutu (Y.3) & 0 & \multicolumn{7}{c}{ Rata-rata keseluruhan } \\
\hline \multicolumn{8}{c}{}
\end{tabular}

Uji Validitas dan Reliabilitas Instrumen Penelitian

Sebelum dilakukan analisis, terlebih dahulu dilakukan uji validitas dan reliabilitas instrument penelitian. Berikut disajikan Uji valditas dan reliabilitas instrument untuk semua variabel penelitian :

Tabel 5 Uji Validitas dan Reabilitas

\begin{tabular}{lcccc}
\hline \multicolumn{1}{c}{ Variabel } & Indikator & Korelasi & Keterangan & Alpha Cronbach \\
\hline Profesional & X11 & 0.746 & Valid & 0.901 \\
(X1) & X12 & 0.826 & Valid & \\
& X13 & 0.738 & Valid & \\
X14 & 0.852 & Valid & \\
X15 & 0.812 & Valid & \\
Personal & X16 & 0.774 & Valid & \\
(X2) & X21 & 0.790 & Valid & 0.925 \\
& X22 & 0.866 & Valid & \\
Manajemen & X23 & 0.894 & Valid & \\
(X3) & X31 & 0.840 & Valid & 0.921 \\
& X32 & 0.585 & Valid & \\
& X33 & 0.875 & Valid & \\
Kualitas Pelaksanaan & X34 & 0.778 & Valid & \\
(Y) & X35 & 0.874 & Valid & \\
& Y11 & 0.889 & Valid & 0.842 \\
\hline
\end{tabular}

Berdasarkan tabel diatas, terlihat bahwa semua nilai korelasi lebih besar dari 0.3 sehingga validitas instrument terpenuhi atau dengan kata lain instrument dikatakan valid. Nilai alpha Cronbcah untuk semua variabel lebih besar dari 0.6 sehinggan semua indikator dalam penelitian dikatak reliable dan dapat digunakan untuk analisis selanjutnya.

\section{Hasil Analisis SEM}

Uji Asumsi SEM
Uji asumsi meliputi normalitas dan tidak adanya outlier. Asumsi normalitas multivariate diuji dengan bantuan software AMOS 6 pada Lampiran 3, menunjukkan bahwa secara multivariate data tidak berdistribusi normal. Hal ini diindikasikan pada nilai critical ratio sebesar 4.883 dengan nilai kritis Z- ${ }_{\text {hitung }}$ untuk a 5\% adalah sebesar 1.96. Karena nilai mutlak CR untuk multivariate sebesar 4.883 > 1.96 maka asumsi normalitas multivariate tidak terpenuhi. Namun demikian, berdasarkan dalil limit pusat jika sampel semakin besar (>30) maka statistik akan berdistribusi normal. Dengan besar sampel $n=50$, maka data sudah 
memenuhi dalil limit pusat, sehingga asumsi normalitas data tidak bersifat kritis dan dapat diabaikan.

Untuk menguji ada tidaknya outlier, dapat dilihat dengan mahalanobis distance (Md). Mahalanobis distance adalah suatu jarak yang mengukur jauh dekatnya titik pusat data "rata-rata" dengan masingmasing titik observasi. Dalam kasus ini titik observasi adalah nomor kuisioner dari responden. Pemeriksaan terhadap oultiers multivariat dilakukan menggunakan kriteria mahalanobis pada tingkat $\mathrm{p}<0.001$. Mahalanobis distance dievaluasi menggunakan $\chi^{2}$ pada derajat bebas sebesar banyaknya paramter dalam model yang digunakan yaitu $=59$ dimana dari tabel statistik diperoleh $\chi_{83}^{2}=98.324$ Kaidah pengambilan keputusan, jika Md dari titik obeservasi > 98.324 maka dikatakan bahwa titik observasi itu adalah outlier, sedangkan jika Md dari titik observasi $<98.324$ maka dikatakan bahwa titik observasi itu bukan suatu outlier.

Dari tabel Mahalanobis distance (Lampiran 3) dapat dilihat bahwa titik observasi yang paling jauh adalah responden ke 23 dengan nilai $\mathrm{Md}=34.341$. Jika dibandingkan dengan nilai $=98.324$ maka nilai Md titik ke-23 < 98.324, maka disimpulkan bahwa semua titik observasi bukan merupakan outlier.

\section{Hasil Analisis Goodness of Fit SEM}

Model teoritis pada kerangka konseptual penelitian, dikatakan fit jika didukung oleh data empirik. Hasil pengujian goodness of fit overall model, sesuai dengan hasil analisis SEM pada Lampiran 4, guna mengetahui apakah model hipotetik didukung oleh data empirik, diberikan pada gambar dan tabel di bawah ini.

Hasil pengujian Goodness of Fit Overall berdasarkan Gambar, Menurut Arbuckle dan Wothke, dalam Solimun (2009), kriteria terbaik yang digunakan sebagai indikasi kebaikan model adalah nilai RMSEA yang di bawah 0.08. Pada penelitian ini, nilai RMSEA sebesar $0.048<0.08$. Oleh karena itu model SEM pada penelitian ini cocok dan layak untuk digunakan.

\section{Model Pengukuran}

Model pengukuran diukur dari nilai loading factor (standardize coefficient) pada setiap indikator ke variabel laten. Nilai loading factor menunjukkan bobot dari setiap indikator sebagai pengukur dari masing-masing variabel. Indikator dengan loading factor besar menunjukkan bahwa indikator tersebut sebagai pengukur variabel yang terkuat (dominan).

Hasil analisis faktor konfirmatori terhadap indikator-indikator dari keempat variabel penelitian dapat dilihat pada tabel berikut.

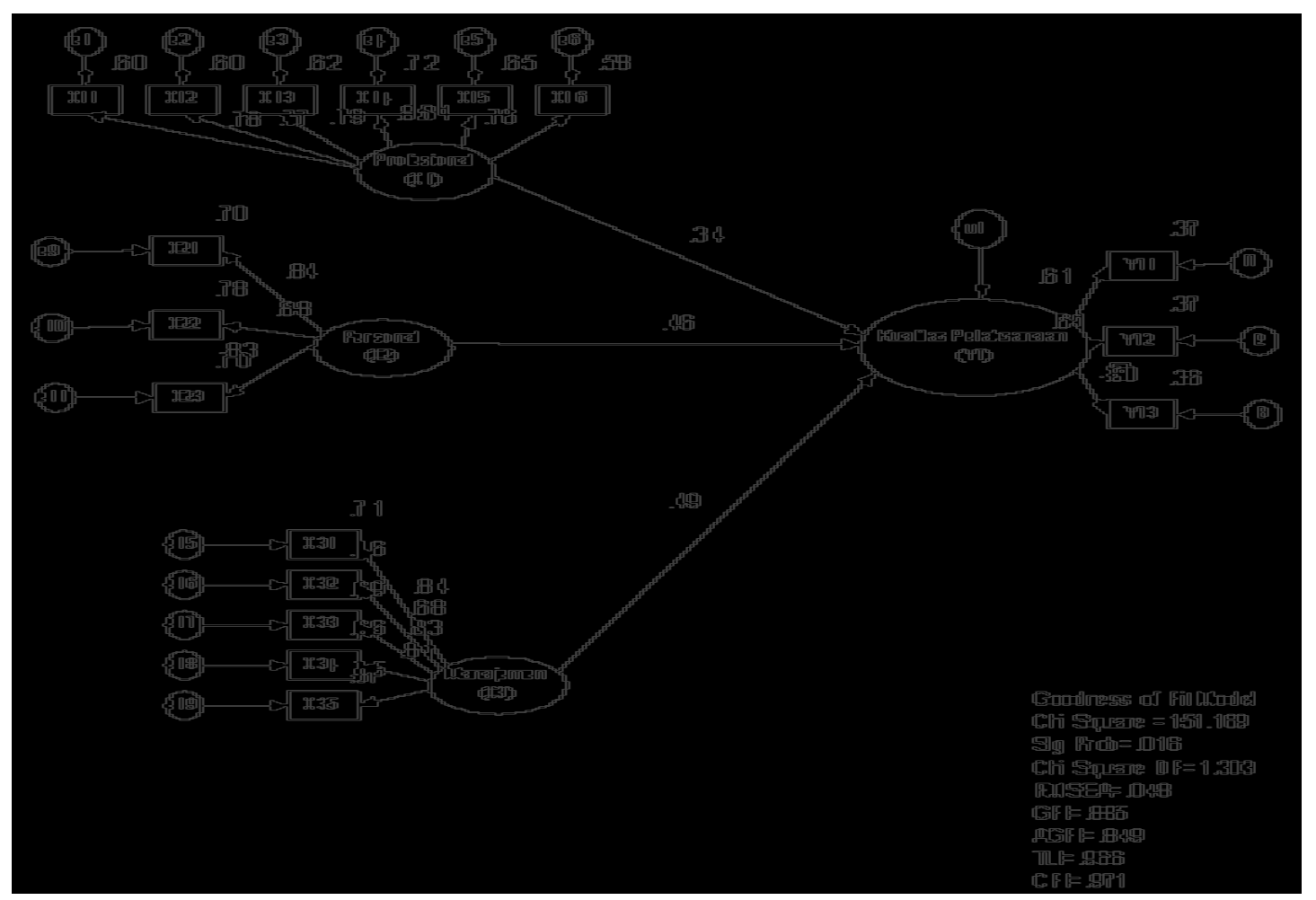

Gambar 1. Diagram Jalur Hasil Analisis SEM 
Tabel 6. Hasil Pengujian Measurement Model Variabel Profesional (X1)

\begin{tabular}{ccc}
\hline Indikator & Standardize & P-Value \\
\hline Gambar Kerja (X1.1) & 0.777 & 0.000 \\
Pengawasan (X1.2) & $\mathbf{0 . 8 4 9}$ & 0.000 \\
Estimasi (X1.3) & 0.788 & 0.000 \\
Keselamatan Kerja & 0.774 & 0.000 \\
(X1.4) & & \\
Jadwal Kerja (X1.5) & 0.808 & 0.000 \\
Kualitas Bahan (X1.6) & 0.762 & 0.000 \\
\hline
\end{tabular}

Tabel 7. Hasil Pengujian Measurement Model Variabel Personal (X2)

\begin{tabular}{ccc}
\hline Indikator & Standardize & P-Value \\
\hline $\begin{array}{c}\text { Pengalaman Kerja } \\
\text { (X2.1) }\end{array}$ & 0.835 & 0.000 \\
$\begin{array}{c}\text { Seleksi (X2.2) } \\
\text { Komitmen membangun } \\
\text { kepercayaan dan }\end{array}$ & $\mathbf{0 . 8 8 4}$ & 0.000 \\
komunikasi (X2.3) & 0.834 & 0.000 \\
\hline
\end{tabular}

Sumber: Data Penelitian Diolah, 2012 (Lampiran 4)

Berdasarkan Tabel di atas, Indikator pertama yaitu Pengalaman kerja mempunyai nilai loading factor sebesar 0.835 dengan p-value sebesar 0.000 . Karena p-value $<0.05$, maka dapat dikatakan bahwa indikator Pengalaman kerja signifikan dalam mengukur variabel Personal.

Indikator kedua yaitu seleksi mempunyai nilai loading factor sebesar 0.884 dengan p-value sebesar 0.000 . Karena p-value $<0.05$, maka dapat dikatakan bahwa indikator seleksi signifikan dalam mengukur variabel Personal.

Indikator ketiga yaitu komitmen membangun kepercayaan dan komunikasi mempunyai nilai loading factor sebesar 0.834 dengan p-value sebesar 0.000 . Karena p-value $<0.05$, maka dapat dikatakan bahwa indikator komitmen membangun kepercayaan dan komunikasi signifikan dalam mengukur variabel Personal.

Berdasarkan tabel di atas, terlihat bahwa ketiga indikator secara signifikan mengukur variabel Personal karena setiap indikator memiliki nilai P-value $<0.05$. Dari besarnya koefisien SEM Standardize tertinggi diperoleh informasi bahwa indikator $\mathbf{X} 2.2$ yaitu seleksi adalah indikator terkuat pengukur variabel Personal.

\section{Tabel 8. Hasil Pengujian Measurement Model Variabel Manajemen (X3}

\begin{tabular}{ccc}
\hline Indikator & Standardize & P-Value \\
\hline Pengarahan (X3.1) & 0.840 & 0.000 \\
Pemahaman (X3.2) & 0.677 & 0.000 \\
Financial dan & $\mathbf{0 . 8 6 8}$ & 0.000 \\
Likuiditas (X3.3) & 0.812 & 0.000 \\
Insentive (X3.4) & 0.000 \\
Penyelesaian Konflik & 0.829 & \\
(X3.5) & & \\
\hline
\end{tabular}

Berdasarkan Tabel di atas, Indikator pertama yaitu pengarahan mempunyai nilai loading factor sebesar 0.840 dengan p-value sebesar 0.000. Karena p-value $<0.05$, maka dapat dikatakan bahwa indikator pengarahan signifikan dalam mengukur variabel Personal.

Indikator kedua yaitu pemahaman mempunyai nilai loading factor sebesar 0.677 dengan p-value sebesar 0.000. Karena p-value $<0.05$, maka dapat dikatakan bahwa indikator pemahaman signifikan dalam mengukur variabel Personal.

Indikator ketiga yaitu financial dan likuiditas mempunyai nilai loading factor sebesar 0.868 dengan p-value sebesar 0.000. Karena p-value $<0.05$, maka dapat dikatakan bahwa indikator financial dan likuiditas signifikan dalam mengukur variabel Personal.

Indikator keempat yaitu Insentive mempunyai nilai loading factor sebesar 0.812 dengan p-value sebesar 0.000. Karena p-value $<0.05$, maka dapat dikatakan bahwa indikator Insentive signifikan dalam mengukur variabel Personal.

Indikator kelima yaitu Penyelesaian Konflik mempunyai nilai loading factor sebesar 0.829 dengan p-value sebesar 0.000. Karena p-value $<0.05$, maka dapat dikatakan bahwa indikator Penyelesaian Konflik signifikan dalam mengukur variabel Personal.

Berdasarkan tabel di atas, terlihat bahwa kelima indikator secara signifikan mengukur variabel Manajemen karena setiap indikator memiliki nilai Pvalue $<0.05$. Dari besarnya koefisien SEM Standardize tertinggi diperoleh informasi bahwa indikator X3.3 yaitu Financial dan Likuiditas adalah indikator terkuat pengukur variabel Manajemen. 


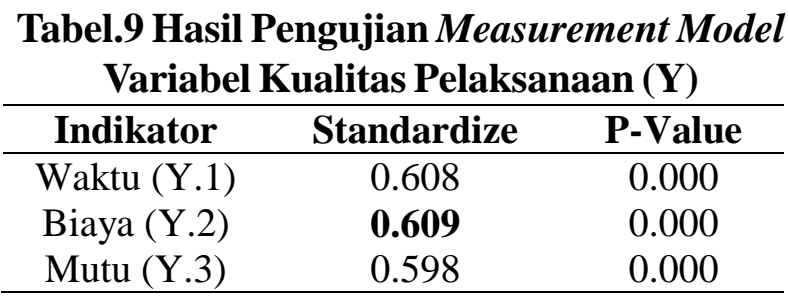

Berdasarkan Tabel di atas, Indikator pertama yaitu waktu mempunyai nilai loading factor sebesar 0.608 dengan $p$-value sebesar 0.000 . Karena p-value $<0.05$, maka dapat dikatakan bahwa indikator waktu signifikan dalam mengukur variabel Personal.

Indikator kedua yaitu Biaya mempunyai nilai loading factor sebesar 0.609 dengan p-value sebesar 0.000 . Karena p-value $<0.05$, maka dapat dikatakan bahwa indikator Biaya signifikan dalam mengukur variabel Personal.
Indikator ketiga yaitu mutu mempunyai nilai loading factor sebesar 0.598 dengan p-value sebesar 0.000 . Karena p-value $<0.05$, maka dapat dikatakan bahwa indikator mutu signifikan dalam mengukur variabel Personal.

Berdasarkan tabel di atas, terlihat bahwa ketiga indikator secara signifikan mengukur variabel Kualitas Pelaksanaan karena setiap indikator memiliki nilai Pvalue $<0.05$. Dari besarnya koefisien SEM Standardize tertinggi diperoleh informasi bahwa indikator Y.2 yaitu Biaya adalah indikator terkuat pengukur variabel Kualitas Pelaksanaan.

\subsubsection{Model Struktural}

Dalam model struktural ini, diuji seepuluh hubungan antar variabel. Berikut disajikan secara lengkap hasil pengujian hubungan antar variabel penelitian sebagai berikut:

Tabel 10. Model Struktural Hasil SEM

\begin{tabular}{cccl}
\hline $\begin{array}{c}\text { Hubungan } \\
\text { Antar Variabel }\end{array}$ & $\begin{array}{c}\text { Koefi } \\
\text { sien }\end{array}$ & $\begin{array}{c}\text { P- } \\
\text { value }\end{array}$ & Keterangan \\
\hline $\begin{array}{c}\text { Profesional } \rightarrow \\
\text { Kualitas Pelaksanaan }\end{array}$ & 0.344 & 0.001 & Signifikan \\
$\begin{array}{c}\text { Personal } \rightarrow \text { Kualitas } \\
\text { Pelaksanaan } \\
\begin{array}{c}\text { Manajemen } \rightarrow \\
\text { Kualitas Pelaksanaan }\end{array}\end{array}$ & 0.459 & 0.000 & Signifikan \\
\hline
\end{tabular}

\section{KESIMPULAN DAN SARAN}

\section{Kesimpulan}

a. Faktor yang mempengaruhi kompetensi mandor terhadap kinerja kualitas pelaksanaan kontruksi gedung di Malang Raya adalah kompetensi ketrampilan, personal dan manajemen.

b. Hubungan dari variabel-variabel yang yang mempengaruhi kompetensi mandor terhadap kualitas pelaksanaan kontruksi gedung di Malang Raya dari hasil analisis dan pembahasan, sebagai berikut :

1. Terdapat pengaruh yang signifikan antara Variabel Ketrampilan yang terdiri dari gambar kerja, pengawasan,estimasi, keselamatan kerja, jadwal kerja dan kualitas bahan terhadap Kualitas Pelaksanaan. Artinya semakin tinggi nilai Ketrampilan, semakin tinggi pula nilai Kualitas Pelaksanaan.
2. Terdapat pengaruh yang signifikan antara Variabel Personal yang terdiri dari pengalaman kerja, seleksi serta komitmen membangun kepercayaan dan komunikasi terhadap Kualitas Pelaksanaan. Artinya semakin tinggi nilai Personal, semakin tinggi pula nilai Kualitas Pelaksanaan.

3. Terdapat pengaruh yang signifikan antara Variabel Manajemen yang terdiri dari Pengarahan, Pemahaman, Financial dan Likuiditas, Insentive serta Penyelesaian konflik terhadap Kualitas Pelaksanaan. Artinya semakin tinggi nilai Manajemen, semakin tinggi pula nilai Kualitas Pelaksanaan.

\section{Saran}

Dari hasil analisis dan kesimpulan yang dipaparkan di atas, maka rekomendasi penelitian yang dapat diajukan adalah sebagai berikut: 
1. Perlu adanya penelitian lebih lanjut untuk jenisjenis pekerjaan lainnya sehingga dapat diketahui kompetensi mandor secara lebih mendalam.

2. Penelitian lebih lanjut diharapkan dapat ditujukan untuk jenis pekerjaan lainnya seperti pekerjaan jalan dan pekerjaan sipil bidang keairan.

3. Cakupan wilayah penelitian selanjutnya perlu diperluas jangkauannya misal tingkat provinsi, sehingga kesimpulan dari populasi yang diamati dapat lebih banyak.

\section{DAFTAR PUSTAKA}

Abdel Razek R.H, September-October 1998, Quality Improvement in Egypt: Methodology and Implementation, Journal of Construction Engineering and Management, ASCE.

Barrie D.S dkk, 1995, Manajemen Proyek Profesional, Erlangga, Jakarta.

Budiman, A, Kamus Istilah Teknik Sipil, Bandung, 1991. Hal 103

Cheng Li, Love, Januari-Februari 2000, Esthablishment of Critiical Sucsess Factor for Construction Partnering, Journal of Management in Engginering, ASCE.

Choromokos J.Jr, Mckee K.E, March 1981, Construction Productivity Improvement, Journal of The Construction Division, Vol 107, ASCE.

De Saram D.D, Ahmed S.M, October 2001, Construction Coordination Activities: What is Important and What Consumes Time, Journal of Management in Engineering, ASCE.

Gao Smith, Michin, October 2002, Budget and schedule Success for Small Capital-Facility Project, Journal of Management in Engginering, ASCE.

Gardiner P D, Simon J E, January-Februari 1998, Conflict in Small And Medium Sized Project: Case of Partnering to The Rescue, Management in Engginering, ASTE.
Goodman R.E, Chinowsky P.S, January-February 2000, Taxonomy of Knowledge Requirements for Construction Executives, Journal of Mangemen in Engineering, ASCE.

Guevera J.M, boyer L.T, March 1981, Communication Problem within Construction, Journal of Construction Engineering and Management, Vol. 107, ASCE.

Hinze J K, Maret 1981, Poductive Foremen Characteristic, Journal of Countruction Divition, ASCE.

Juran, 1995, kepemimpinan Mutu, Pustaka Binaman Pressindo, Jakarta.

Kumaraswarny M.M, Mathews J.D, JanuaryFebruary 2000, Improved Subcontractor Selection Employing Partnering Principles, Journal of Management in Engineering, ASCE.

Ling Y.Y, September-October 2002, Model for Predicting Performance of Architects and Engineers, Journal of Construction Engineering and Management, ASCE.

Loosemore M, May-June 1998, Psychology of Accident Prevention in The Construction Industry, Management in engineering, ASCE.

Maloney F.W, Mc Fillen J, 1987, Influence of Foremen on Performance, Journal of Construction Engineering and Management, Vol 113, ASCE.

Poerwadarminta, W.J.S, Kamus Umum Bahasa Indonesia, Jakarta, Balai Pustaka, 1985, hal 630.

Santoso S, 2000, SPSS Statistik Parametrik, elex Media Computindo, Jakarta.

Senior B.A, December 1996, Electrical Construction Foremen Task Scheduling, Journal of Construction Engineering and Management, Vol. 122, ASCE.

Singarimbun M, Effendi S, 1989, Metode Penelitian Survai, LP3ES, Jakarta. 
Soedaroe B, 2000, Pengaruh Kompetensi Mandor Terhadap Kinerja Pelaksanaan Konstruksi Struktur Gedung Beringkat di Jakarta, Tesis, Universitas Indonesia, Jakarta.

Sugiyono, 1999, Statistik Nonparametris untuk Penelitian, Alfabeta, Bandung.

Zen, A, 1997, Sumber Daya Manusia Sektor Informal jasa Konstruksi, Jakarta, Pekerjaan Umum 